\title{
Biosphere Reserve as a Learning Tourism Destination: Approaches from Tasik Chini
}

\author{
A. Habibah ${ }^{1,2}$, I. Mushrifah ${ }^{1}$, J. Hamzah ${ }^{1,2}$, A. Buang ${ }^{1}$, M. E. Toriman ${ }^{2,3}$, S. R. S. Abdullah ${ }^{1,4}$, \\ K. Z. Nur Amirah", Z. Nur Farahin', A. C. Er ${ }^{2}$ \\ ${ }^{1}$ Pusat Penyelidikan Tasik Chini, Faculty of Science and Technology, Universiti Kebangsaan Malaysia, Bangi, Malaysia \\ ${ }^{2}$ School of Social, Development and Environmental Studies, Faculty of Social Sciences and Humanities, \\ Universiti Kebangsaan Malaysia, Bangi, Malaysia \\ ${ }^{3}$ Universiti Sultan Zainal Abidin, Terengganu, Malaysia \\ ${ }^{4}$ Faculty of Engineering and Built Environment, Universiti Kebangsaan Malaysia, Bangi, Malaysia \\ Email: ha@ukm.my
}

Received November 2, 2013; revised November 28, 2013; accepted December 14, 2013

Copyright (C) 2013 A. Habibah et al. This is an open access article distributed under the Creative Commons Attribution License, which permits unrestricted use, distribution, and reproduction in any medium, provided the original work is properly cited. In accordance of the Creative Commons Attribution License all Copyrights (C) 2013 are reserved for SCIRP and the owner of the intellectual property A. Habibah et al. All Copyright (C) 2013 are guarded by law and by SCIRP as a guardian.

\begin{abstract}
Biosphere Reserves (BR) are special areas or regions highly recognized for their conservation, logistic functions and sustainable development initiatives. However, not much work has explored into the BRs' roles or functions as tourism learning destination, especially during the early years of their recognition as BR. This article aims to identify the mechanism utilised in the learning tourism function at Tasik Chini Biosphere Reserve since its inception in 2009 to the present year of 2013. The results reveal that learning of science and culture of the locals are the two-tier perspectives utlised in conceptualizing a tourism learning destination. Activities introduced in the specific themes of The Sustainability of Tropical Heritage fulfil the fundamental need of deep learning of scientific research and learning of the BR's ecosystem, while the Ecosystem Health fulfils both deep and surface learning of the young visitors. The cultural knowledge of the community, on the other hand, offers a unique and authentic experience to the learners or visitors. As a learning tourism destination, the learning community, nevertheless, expects that the standard of tourism services should not be marginalised and must meet the high standard of tourism services. It is imperative that the science of Biosphere Reserve and the local culture are linked to set a holistic foundation in the creation of the learning programmes at the Tasik Chini Biosphere Reserve.
\end{abstract}

Keywords: Learning Tourism Destination; Ecotourism; Tasik Chini Biosphere Reserve; Deep Learning

\section{Introduction}

Biosphere Reserves (BR) are highly acknowledged as areas or regions for undertaking learning, reconciling environmental issues and integrating approaches for sustainable development. This is especially apparent in the three complementary and mutual functions of biodiversity conservation; sustainable economic and human development; and logistics support for research, monitoring, education and information exchange [1-4]. During the United Nations Decade of Education for Sustainable Development (UNDESD, 2004-2013), another special responsibility given to the $\mathrm{BR}$ is to function as a learning laboratory or learning site, where evidence-based knowledge, iterative and practical principles are utilised to en- sure sustainable development [1,5]. This mission and aspiration further demand salient approaches as learners now are not limited to only small groups of locals; instead, it is intended to cater to a wider international community [6,7].

Whilst extensive documentations on successful learning functions or sites provide references to the policy makers and practitioners in the recent years [8-13], what constitutes a good model of a learning destination for a newly endorsed site still remains limited. There is no agreed and well defined learning destination that offers a holistic orientation and specific-site knowledge. To date, social learning [14], ecosystem approach $[9,15]$ and systems thinking approach $[5,16,17]$, learning tourism destination 
(LTD) or TLA (Tourism learning area) [18-20], CARE approach (complexity, aesthetic, responsibility and ethics), edutourism [21] and experiential learning [22] have been introduced to foster the learning of sustainable development. Of specific roles, the Yukon entrepreneurs [23] have created an interactive tool in product development, and further suggest a change from "product" to "programme" and from "tourist" to "participants" in order to enhance the learning experiences, especially for the special niche market, including the educational tourists.

Although the above-mentioned approaches provide alternatives in realizing the learning objectives and functions of the BRs, some limitations on implementations and acceptance of the stakeholders are still apparent because of the diversity of socio-cultural, physical, economic and environmental background of both visitors and educators [24-27]. The existing literature has yet to provide a holistic mechanism that elucidates the roles of the stakeholders in initiating, inventing and developing the Biosphere Reserve experiences as the foundation of tourism learning destination.

Tasik Chini has been accorded as the first Biosphere Reserve in Malaysia in 2009. Rich in diversity of flora, fauna and culture of aboriginal tribe, Tasik Chini is a sensitive area of class 1 . As a BR, Tasik Chini has to execute three major functional roles, comprising of development, conservation and logistic functions. Of these roles, providing a learning experience is one of the most important logistic functions. Considering that comprehending the learning approaches in Tasik Chini as a new $\mathrm{BR}$ in the Asian region will provide a sharing of sitespecific approaches and knowledge, this article was aimed at identifying the learning initiatives of Tasik Chini Biosphere Reserve and at understanding the learning community's responses to further improve the learning functions of the designated area.

\section{Biosphere Reserve as a Learning Destination}

\subsection{The Science of Biosphere Reserve}

Biosphere reserves, as defined by UNESCO, are areas of terrestrial and coastal ecosystems that promote solutions to reconcile the conservation of biodiversity with its sustainable use. Every single BR has to fulfil conservation, development, and logistic support functions; hence, a BR is commonly agreed as a "living laboratory" or "learning place" $[3,4,17]$. The Seville Strategy elaborates these functions. First is the conservation function which is intended to preserve landscapes, ecosystems, species, and natural resources. Second is the development function which focuses on sustainable economic and human development by considering social, cultural, and ecological issues; and third, the logistic support which is aimed at fostering education, research, and information exchange related to conservation and development of the BR [1].

With the three above aforementioned functions, each BR provides a complete ecosystem that encourages scientific ideas and tools in resolving diverse social-ecological issues. Studies of flora and fauna, ethnobotany of medicinal crops, conservation and forest, wildlife, soil biology and biochemistry of montane habitats as well as hydrology and watershed have been undertaken to comprehend and strengthen the science entity [28-30]. However, sustainable development has become an important function in the mid 1990s, and studies on environmental governance and sustainable development practices have attracted scientists to explore issues on BR [25]. Studies in the Maya forest BR, Long Point and other renowned sites explicitly positioned the science of environmental management and conservation in the biosphere reserve [13,31].

Although it has been the pure sciences that dominated the studies of the BRs, recent works, however, showed a significant integration of multi-disciplines. [32] emphasised that research, and monitoring are fundamental components for the logistics function to provide locationspecific knowledge of ecosystems, local economies, social organizations and governance. These changing roles of logistic functions were found in four biosphere reserves - Long Point, Niagara Escarpment, Mont Saint Hilaire, and Mount Arrow Smith. The research interests have also broadened into the transition zone of biosphere reserves, communities and collaborative approaches.

On a similar vein, [31] offer an alternative for sustainability initiatives emphasising on place-based and integrated-knowledge approaches. These approaches imply a flexible combination of disciplines and types of knowledge in the context of nature-human interactions. They can be operationalised within the framework of sustainability science in three steps: 1) characterize the contextual circumstances that are most relevant for sustainability; 2) identify the disciplines and knowledge that need to be combined to appropriately address contextual circumstances; and 3) decide how these disciplines and knowledge can be effectively combined and integrated. In simple terms, the outcome of the research is relevant to scientific knowledge, and in turn, scientific knowledge makes possible for the practices within the context of local benefit. Furthermore, [3] asserts that a primary platform in learning for sustainable development is the ability to discover new ways in deepening communications with the public, private sector and civil society. All these trends ratify the needs of inventing a mechanism that allow the scientific findings to be transferred to the community and visitors. 


\subsection{The Learning Approaches of the Learning Sites}

It is worth noting the emerging literature on diverse logistic functions of the Biosphere Reserve. The learning and logistic functions exhibit increasingly diverse interests covering topics ranging from purist ecosystem services to the applied researches concerning the visitors' acceptance as well as involvement and benefits of local community. However, recently, there has been a tendency of establishing a learning destination $[5,9,14,15,19$, 20], and as a result, thematic names of these sites emerged significantly. These initiatives are of various levels - area, region, target audiences and collaborations, including with the higher learning institutions, researchers and school children [24,33-37].

Looking into the initiatives shown in Table 1, it is fundamental that each learning approach has a clear and strong foundation of the site-specific knowledge even though rigourous debate on learning about the biosphere reserve is not a new agenda. Since the Seville strategy in the 70 s to the Rio Summit in the 1990s, educational and learning objectives have been the focal points of logistic functions of the BRs. Being a special place that has its specific context knowledge, initiatives in documentation of diverse experiences from the newly established biosphere reserve will provide a large pool of resources on learning. To some scholars, experiential and holistic undertakings of both science and local knowledge are their preference. Similarly, educationists also stress on both tacit and explicit knowledge or deep and surface learning [38,39].

Being recognized as a learning site and at the same time, being promoted as an ecotourism destination and key area of sustainable development, most BRs will ensure a unique local knowledge as part and parcel of their logistic functions [40,41]. In this vein, the cultural heritage of the community will become the key focal experience, and authentic landscape will represent a sound product mix of the BRs. Recent trend shows that local and indigenous culture, traditional ecological knowledge and authentic experience are the buzzword in packaging these experiences.

Table 1. Approaches on learning destinations.

\begin{tabular}{|c|c|c|}
\hline Scholars & Approach & Principle components/Attributes \\
\hline de la Barre (2005) & $\begin{array}{c}\text { Learning travel product } \\
\text { development }\end{array}$ & $\begin{array}{l}\text { Learning travel (also known as "educational travel" or "enrichment travel") is a concept. It } \\
\text { involves a series of formal and informal learning, travel, and social activities that, when } \\
\text { cleverly packaged, engages people in memorable "ad-ventures". Its unique selling proposition } \\
\text { is quality-learning experiences, delivered by dynamic resource specialists. Educational } \\
\text { travelers are willing to pay a premium for these experiences. }\end{array}$ \\
\hline $\begin{array}{l}\text { Khelghat-Doost et al. } \\
\text { (2011) }\end{array}$ & $\begin{array}{l}\text { Regional Centre of } \\
\text { Expertise (RCE) }\end{array}$ & $\begin{array}{l}\text { As evidenced in the Regional Centre of Expertise, (RCE) a framework of partnership that } \\
\text { fosters capacity building and supports innovative education for sustainable development is } \\
\text { proposed. Three key factors are leadership, partnership and networking. }\end{array}$ \\
\hline $\begin{array}{l}\text { Schianetz, Kavanagh, } \\
\text { \& Lockington, (2007) }\end{array}$ & $\begin{array}{l}\text { Learning tourism } \\
\text { destination }\end{array}$ & $\begin{array}{l}\text { The fundamental elements of a learning tourism destination (LTD) are 1) Shared vision and } \\
\text { goals, 2) Information system, 3) Continuous learning and co-operative research, 4) } \\
\text { Co-operation (informal collaboration), 5) Co-ordination (formal collaboration), cultural } \\
\text { exchange that forms the basis for mutual cooperation 6) acceptance of different worldviews } \\
\text { and belief systems, and understanding of these differences which will enhance the dialogue } \\
\text { between individuals and within the community, 7) Participative planning and decision making, } \\
\text { 8) adaptive management }\end{array}$ \\
\hline McCarthy et al. 2011 & $\begin{array}{l}\text { Social learning and } \\
\text { sustainability }\end{array}$ & $\begin{array}{l}\text { Promote social learning through sustainability workshops; ensuring an inclusive, open process } \\
\text { and providing opportunities for increased public understanding of the purpose and role of the } \\
\text { biosphere reserve contribute greatly to social learning. }\end{array}$ \\
\hline European Commission & Tourism Learning area & $\begin{array}{l}\text { A tourism learning area (TLA) is a concept aimed at improving skills in tourism. It is based on } \\
\text { an exchange of learning experiences aimed at increasing quality, innovation and } \\
\text { competitiveness within the industry. A TLA consists of a network of all sectors and individuals } \\
\text { who contribute to tourism (including local authorities, entrepreneurs, learning institutions, } \\
\text { community groups and farmers). }\end{array}$ \\
\hline $\begin{array}{l}\text { Ministry of Education } \\
\text { British Columbia, } 2009\end{array}$ & $\begin{array}{l}\text { CARE concept } \\
\text { C.A.R.E. (Complexity, } \\
\text { Aesthetics, Responsibility } \\
\quad \text { and Ethics) }\end{array}$ & $\begin{array}{l}\text { C.A.R.E. emphasises the interdisciplinary nature of environmental concepts that leads toward } \\
\text { deeper engagement with environmental learning in all of its forms. These principles are: } \\
\text { Complexity: considering the complexity and interrelatedness of natural and human created } \\
\text { systems, and how humans interact with and affect those systems; Aesthetics: developing an } \\
\text { aesthetic appreciation for the natural world that encourages students to learn about and protect } \\
\text { the environment; Responsibility: providing opportunities for students to take responsible action } \\
\text { and explore the environmental impact of their decisions and actions; Ethics: providing } \\
\text { opportunities to practice environmental ethics based on an examination of values that can give } \\
\text { rise to new visions, possibilities and actions. }\end{array}$ \\
\hline
\end{tabular}


Another crucial fact is the content of the activities introduced to the visitors. Studies on various BRs' visitors, young school children, families and youth volunteers, confirm the existence of these differences. A project entitled "breakfast: healthy-regional-sustainable" implemented by the Ryon Biosphere reserve has been recognized as a "project of the UN Decade" [11] that introduces children (from year 3 ) to eat healthily.

The play comprised learning about the groceries they consume, in particular the contents and nutritional values, understanding of healthy eating to climate protection and the values of harmonious family meals. This project, which uses a child-oriented method, employed a "fun" way of bringing various dimensions of healthy eating, social (family) aspects of eating and contribution to the local economy. In contrast, [6] compares the visitor centre in Sweden and Germany's BR, and found that even though the formal way of learning provides ESD contents, touristic and informal learning provide more enjoyment and remembrance.

\section{Materials and Methods}

\subsection{The Study Site}

Tasik Chini is the second largest natural freshwater lake in Malaysia. Spanning a total area of 5085 hectares, Tasik Chini was gazetted as a Reserved Area for public use, specifically for tourism activities in 1989 under the National Land Code 1964. Figure 1 shows the study area. In 2008, a larger overlapping area was designated as a UNESCO Biosphere Reserve, covering the lake catchment area and its feeders, totalling 6951.44 hectares.

The water body comprises of 12 interconnected open water bodies called "laut" by the local Orang Asli communities (Tasik Chini dossier, 2009). The indigenous Jakun tribe lives around the lakeshore and the surrounding areas [42]. The water body of the lake covers an estimated 202 hectares of open water and 700 hectares of riparian and wetland zones. Tasik Chini itself is surrounded by natural hills and lowland dipterocarp forests, disturbed forests, vegetated low hills and undulating land which constitute the watershed of the region.

Due to encroachment of catchment area, forest clearing, incompatible land use, and lack of clear guidelines for management and conservation, Tasik Chini suffers from extreme environmental degradation [43]. Considering that strong scientific research can serve as a platform to conserve and restore Tasik Chini, the Tasik Chini Research Centre (TCRC) was established in 2004. With Tasik Chini accorded the status of a UNESCO Biosphere Reserve, environmental problems need to be addressed, and restoration needs to be enhanced. In fact, it should be suitably managed, and re-established as the premier resource-based tourism destination as well as a living laboratory for research and education in Malaysia. Hence, with the situation described above, Tasik Chini has extensive resources as a Learning Destination of Biosphere Reserve.

\subsection{Data Collection and Analysis}

This study used a mixed method approach and the following data collection was utilized in comprehending the approaches initiated in Tasik Chini. The first was the data bank of the TCRC; which provided information regarding the series of events held from 2008 to 2013. The

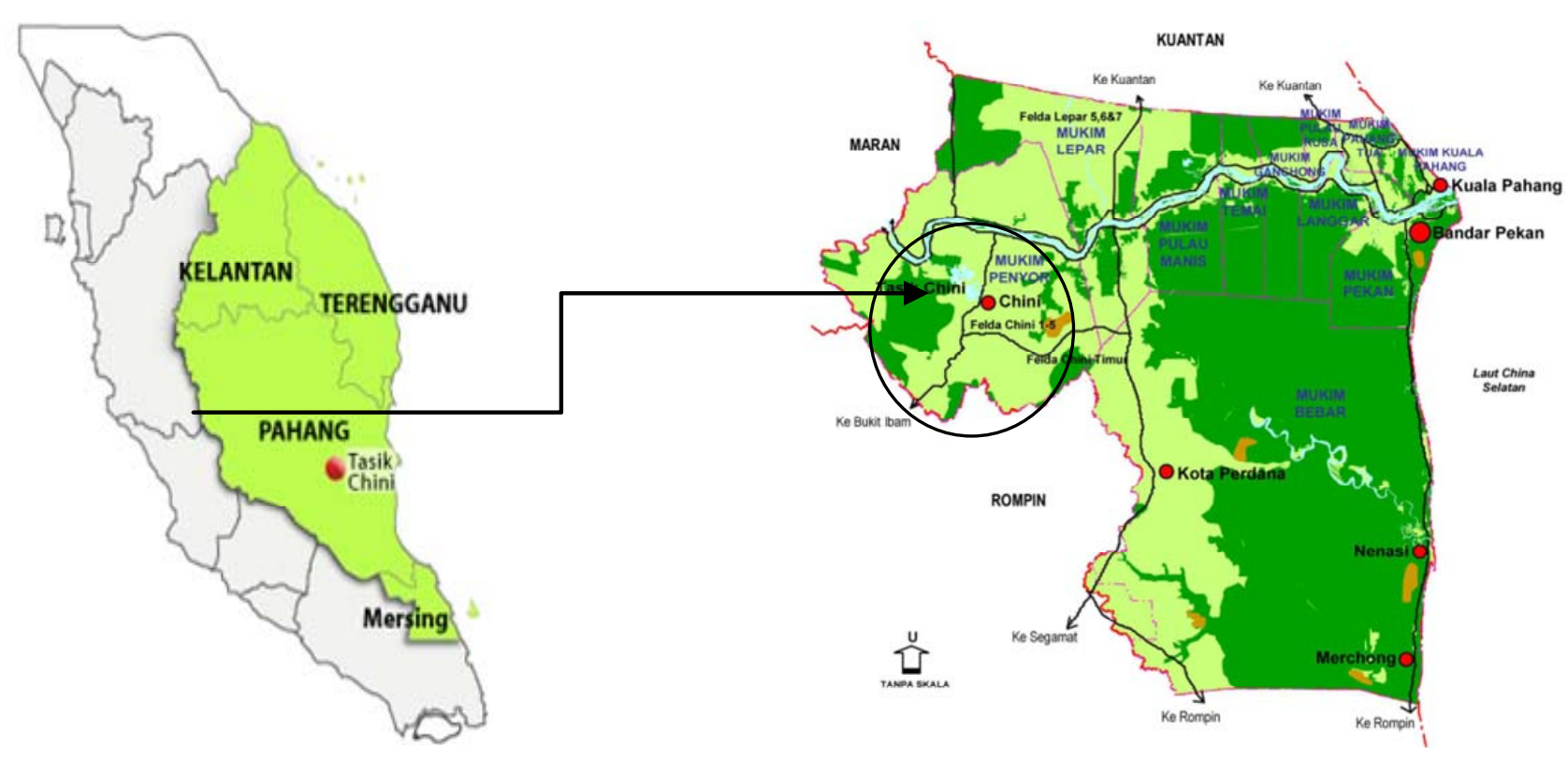

Figure 1. Location of the Study Area, Tasik Chini Biosphere Reserve. 
data provided all events or programmes held at and by the research centre, and among others, included the proposals, event reports and program book. The data has helped the authors to classify and map events into knowledge orientation, scientific and play entity, duration, location and learning objectives as well as to identify the learning community - the participants and experts involved.

The data were further divided into two stages, comprising of events during pre-dossier and events during pre-establishment of the Biosphere Reserve as well as recent events hosted by this site. The second was the qualitative data derived from various in-depth interviews with local stakeholders, participants in the focus group discussion and public consultation. The third was utilisation of the surveys conducted during each programme, especially to derive the participants' feedback, satisfaction and understanding of the overall programmes held and experienced.

\section{Results and Analysis}

\subsection{The Learning Approaches from Tasik Chini}

\subsubsection{Learning of the Science of Biosphere Reserve}

As revealed, learning is one of the logistic functions of BRs; and thus, Tasik Chini has initiated knowledgebased programs in order to promote and provide site spe- cific knowledge and experiences. Since its inception in 2009 , a total of 14 programs have been conducted up to August 2013 during the pre-dossier preparation, preestablishment and post establishment, as depicted in Table 2 .

Each programme provided a thematic understanding of the BR. To ensure visitors have satisfactory experience, each programme was tailor-made according to the educational background, travel motives and duration of visit. Scientific aspects were sought from experts in the pure science and social sciences, especially in terms of knowledge, real-life experiences and hospitality of the locals. These experts provided in-depth knowledge of the major domains of the ecosystem - the lake, hydrology, forest, tourism, aborigines and culture as well as conservation initiatives, which were later moulded into holistic knowledge of this BR [44].

\subsubsection{The Sustainability of Tropical Heritage}

As a host, Tasik Chini is proactively developing a site specific theme of learning ecosystem. A specific theme, namely namely "The Sustainability of Tropical Heritage" is used in hosting the mobility program. A framework of learning culture in four-dimensional perspectives is utilized in this programme. Figure 2 shows the four-dimensional perspectives of the learning culture in Tasik Chini Biosphere Reserve (TCBR). Based on the details of the

Table 2. Events Hosted by Tasik Chini, 2004-2013.

\begin{tabular}{|c|c|c|c|c|c|c|}
\hline \multicolumn{2}{|l|}{ Year of event } & \multirow{2}{*}{$\begin{array}{c}\text { Name of event } \\
\text { Tasik Chini } \\
\text { Expedition } 2004\end{array}$} & \multirow{2}{*}{$\begin{array}{c}\text { Medium of interaction } \\
\text { On site experience }\end{array}$} & \multirow{2}{*}{$\begin{array}{c}\text { Location } \\
\text { At the destination }\end{array}$} & \multirow{2}{*}{$\begin{array}{c}\begin{array}{c}\text { Level } \\
\text { of event }\end{array} \\
\text { State }\end{array}$} & \multirow{2}{*}{$\begin{array}{c}\text { Mode of the } \\
\text { Learning Destination } \\
\text { Scientific expedition and } \\
\text { Real experience }\end{array}$} \\
\hline $\begin{array}{l}\text { Pre-dossier } \\
\text { preparation }\end{array}$ & 2004 & & & & & \\
\hline \multirow[t]{5}{*}{$\begin{array}{l}\text { Pre-establishment } \\
\text { of Tasik Chini as } \\
\text { BR }\end{array}$} & 2008 & $\begin{array}{l}\text { Public consultation } \\
\text { events and World } \\
\text { café Booth }\end{array}$ & $\begin{array}{l}\text { Booth and event that stages the } \\
\text { Tasik Chini Biosphere reserve }\end{array}$ & At the destination & National & $\begin{array}{c}\text { Science of Biosphere reserve, } \\
\text { conservation, development } \\
\text { and education }\end{array}$ \\
\hline & 2009 & $\begin{array}{c}\text { Adopted Village } \\
\text { of UKM }\end{array}$ & Booth and play & $\begin{array}{l}\text { Johor, outside } \\
\text { destination }\end{array}$ & State & Informed knowledge \\
\hline & 2010 & $\begin{array}{c}\text { Celebrating UKM's } \\
40 \text { Years }\end{array}$ & Booth and hands on activities & $\begin{array}{l}\text { Bangi, Universiti } \\
\text { Kebangsaan Malaysia }\end{array}$ & University & $\begin{array}{l}\text { Disseminating knowledge } \\
\text { to public and educational } \\
\text { institution audience }\end{array}$ \\
\hline & 2010 & Mobility program & $\begin{array}{l}\text { On site experience, lake, forest } \\
\text { and community living }\end{array}$ & At the destination & International & $\begin{array}{l}\text { Science and play to } \\
\text { international students }\end{array}$ \\
\hline & 2011 & UNESCO DAY & Booth and event & $\begin{array}{l}\text { Kuala Lumpur, } \\
\text { capital city }\end{array}$ & National & $\begin{array}{l}\text { Disseminating knowledge } \\
\text { to public and international } \\
\text { audience }\end{array}$ \\
\hline Current events & 2011 & Mobility program & $\begin{array}{l}\text { On site experience, lake, forest } \\
\text { and community living }\end{array}$ & At the destination & International & $\begin{array}{l}\text { Science and play to } \\
\text { international students }\end{array}$ \\
\hline & 2011 & $\begin{array}{c}\text { Knowledge } \\
\text { ecotourism event }\end{array}$ & Booth and talk & Bangi, UKM & National & $\begin{array}{c}\text { Disseminating knowledge to } \\
\text { public, tourism providers and } \\
\text { ministry }\end{array}$ \\
\hline & 2012 & Mobility program & $\begin{array}{l}\text { On site experience, lake, forest } \\
\text { and community living }\end{array}$ & At the destination & International & $\begin{array}{c}\text { Science and play to } \\
\text { international students }\end{array}$ \\
\hline & 2012 & Scientific visit & On site experience, lake, forest & At the destination & Regional & Science based activities \\
\hline & 2012 & $\begin{array}{l}\text { Educational } \\
\text { workshop }\end{array}$ & On site and living lab & At the destination & State & Science based activities \\
\hline & 2013 & $\begin{array}{c}\text { Composting } \\
\text { awareness and } \\
\text { knowledge transfer }\end{array}$ & On site and living lab & At the destination & Local & $\begin{array}{l}\text { University-Community } \\
\text { Engagement }\end{array}$ \\
\hline
\end{tabular}




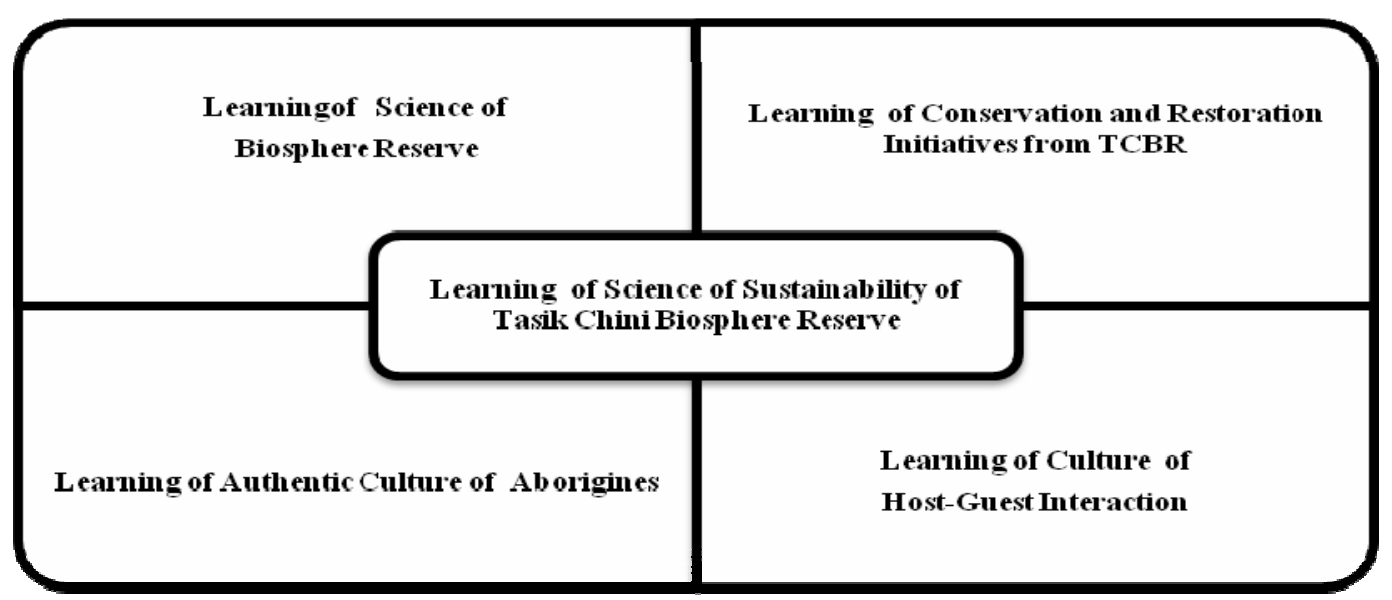

Figure 2. The Learning of Science of Sustainability of Tasik Chini Biosphere Reserve.

activities, four major themes seem to uphold the content and context of the site, namely 1) learning about and for biodiversity; 2) conservation and rehabilitation; 3) cultural, social and livelihood; and 4) local hospitality. These themes were then matched with the duration of the visit, visitors' segmentation and their knowledge background.

The learning of culture of sustainability introduces the ecosystem of the Biosphere Reserve. This is because through the understanding of the ecosystem, the students would be capable of appreciating the livelihood in the area. This is particularly important as the learning provides the characteristics of the physical, biological and cultural setting. Secondly, as the site offers a different entity of an ecosystem, learning about the culture will showcase how each site approach issues of sustainability, including conservation and restoration. Thirdly, learning about the culture means a closer context with the livelyhood of the community. At this stage, real examples are demonstrated to capture students' understanding, acceptance and critical mind, and most importantly, enthuseasm in the proposed programmes on conservation and sustainable Biosphere Reserve.

The final perspective deals with the hospitality of the host as well as the respect for the host-guest relationship.

This setting is aimed at fostering the learning culture of global students, comprising of the interaction between scholars-students and between students; internationals and the locals.

The students, being active participants, can experience student-centered learning and deep learning compared to the teacher-centered learning and surface learning. Between students, this environment has provided not only generic skills, but life-long learning, specifically on interactions between the locals and international societies. It is anticipated that learning about sustainability of Tropical Heritage could be achieved with the four dimensions mentioned above, especially in learning specific-site knowledge of the Biosphere Reserve (BR). Table 3 shows the details of the activities.

\subsection{Learning about the Ecosystem Health of Tasik Chini}

Tasik Chini's learning community comprised of various segments of visitors, ranging from young school children of the locality and from the neighbouring areas to a more educated youth segment of urban areas. Taking into consideration that the young locals and the neighbouring school children are the "guardian of the BR", a simpler way of understanding this ecosystem was initiated. As such, activities were organised in such a way that learning about the ecosystem's health is simpler even though it was aimed at explaining the complexity of the food chain, especially on the flora and fauna found in the area. Students were engaged in conservation through activities such as planting a tree a day and art therapy. For this programme, the Kolb cycle of learning and five sensory medium of learning were utilized into hands-on activities Apparently, collages presented in scrapbooks prepared by the children, showed the high concern for TCBR's future among the young generation.

On the other hand, the scientific learning and ecotourism experience of the youth visitors were of a moderate level of complexity. Taking into consideration that they have been taught subjects such as biology, chemistry and physics at the matriculation level, programmes offered were more specialised. The programmes comprised both theoretical and practical modules, especially on the ecosystem of the lake, land ecology and diversity of local species. Practices of lake water sampling techniques, small mammal trapping and flora mapping were aligned with their matriculation learning and teaching needs.

\subsection{Learning about the Culture of Tasik Chini}

Envisioned as an ecotourism as well as a learning destination, Tasik Chini will definitely develop its own au- 
Table 3. Activities during The Mobility Programme and The Orientation.

\begin{tabular}{lll}
\hline \multicolumn{1}{c}{ Activities of TCBR } & \multicolumn{1}{c}{ Science } & \multicolumn{1}{c}{ Local culture } \\
\hline $\begin{array}{l}\text { Activity 1: Fishnets set-up } \\
\begin{array}{l}\text { Activity 2: Visit to hatchery site and acclimatization } \\
\text { cage }\end{array}\end{array}$ & $\begin{array}{l}\text { Cultural anthropology and fish } \\
\text { Aquatic and Rehabilitation }\end{array}$ & Fish feedings and naming of fishes. \\
$\begin{array}{l}\text { Activity 3: Water quality and hydrology } \\
\begin{array}{l}\text { Activity 4: Macrophytes sightseeing and fish } \\
\text { harvesting }\end{array}\end{array}$ & Hydrology and Geography & Boating and lake excursion \\
$\begin{array}{l}\text { Activity 5: Traditional Kayaking } \\
\text { Activity 6: Socio-cultural activities and Kelundang } \\
\text { dance }\end{array}$ & Hydrology, Ecology & Walking under the canopy and Tropical Trails \\
Activity 7: Lotus planting and reforestation & Cultural tourism and host's hospitality & $\begin{array}{l}\text { Enjoying the local culture and interaction between } \\
\text { participants. }\end{array}$ \\
Activity 8: Blowpipe & Conservation, lotus and ecosystem & Lotus as the cultural heritage of the locals. \\
\end{tabular}

thentic learning experiences. In this vein, the learning processes will be iterative, tailor-made and involve the community of the BR. In the TCBR, the practice of learning with the locals varies according to the audience or visitors' needs or requests. Figure 3 shows some scenes from the learning programmes on the local culture of Tasik Chini.

\subsubsection{The Kelundang Dance}

The Kelundang Dance is one of the cultural traditions inherited from the ancestors. Often staged and performed during special ceremonies among the Jakun tribe, the cultural dance fits well with members of the community. Over the years, however, this tradition has been diminishing from the community's cultural landscape and livelihood.

Their performances only seem to be staged when requested by the tourism providers. Realising that this tradition needs to be conserved and inherited, the TCRC took several initiatives in ensuring that the Kelundang Dance becomes the native tradition, including 1) stating it as one of their tradition in the dossier of Tasik Chini; in which many of their events seem to showcase this dance, and 2) forming a cultural group of young school children to ensure sustainability, with special songs/lyric to be enjoyed by the guests.

\subsubsection{Weaving the Jari Lipan}

The Jakun, living closely with nature, possesses untapped skills in handicrafts. Even though handicraft making is considered domestic work among females, it is through the public consultation and awareness initiated by the PPTC's events that they were informed of opportunities to produce and commercialize local crafts. Besides making them involved directly in the exhibition, the women were consulted on creative production. These opportunities ensure sustainability of small businesses within the limitation of their capabilities and know how. Feedbacks collected during thematic events held, showed that both locals and international visitors enjoyed learning the Jari Lipan. Even though they were taught by the locals who lack communication skills, especially in English, learning opportunities were noticeably appreciated.

\subsubsection{The Traditional Water Kayaking}

Being in the vicinity of the lake, the community is highly dependent on the lake and its ecosystem. The lake and rivers provide the cheapest mode of transportation and roaming areas, giving them the opportunity to develop their "sampan" or "kayaking" skills. These skills however, seem to have faded from the lake-scape of Tasik Chini. Taking into account the importance of conserving the local culture, this experience was re-created in the learning programmes.

\subsubsection{Challenge for Survival in the Forest Trail}

As the Jakun tribe usually roams the neighbouring forests for food supply, exploring what these forest trails have on offer is therefore an exciting experience. According to the village folks, the forest trails have existed for more than three decades, mostly for the use of backpackers who stayed overnight or longer. During these trails, the tourists were taught the survival skills of the natives in the forest, including cooking with bamboos, making utensils from leaves and getting water naturally from stems and roots. Of recent development, two scientific knowledge trails have been developed, namely the Tempenis and the Kempas trails. With on-going work on the flora and fauna research in Tasik Chini, these forest trails lead to a conservation of rare, threatened and endemic species.

\subsection{Responses from the Learning Community}

As revealed in the literature, a learning site has its own learning community; therefore, it is vital to establish who the learning communities are. To put it simply, segmentation of existing and potential learning community needs 


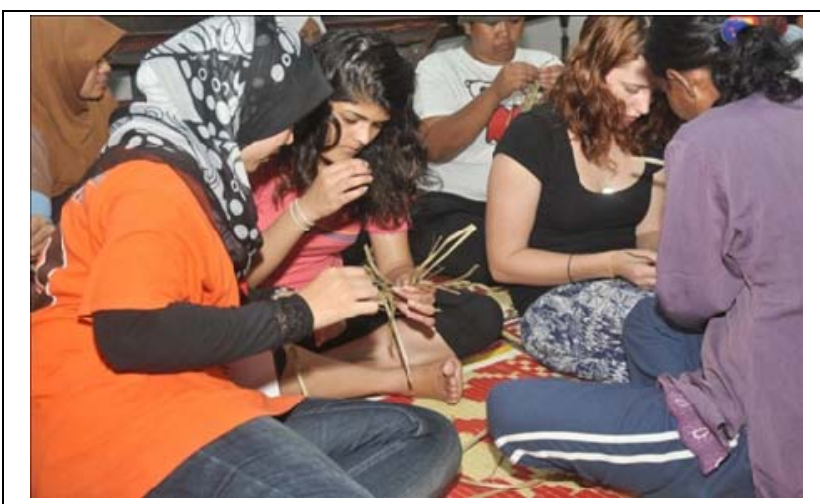

Weaving the Jari Lipan as savouring local handicrafts

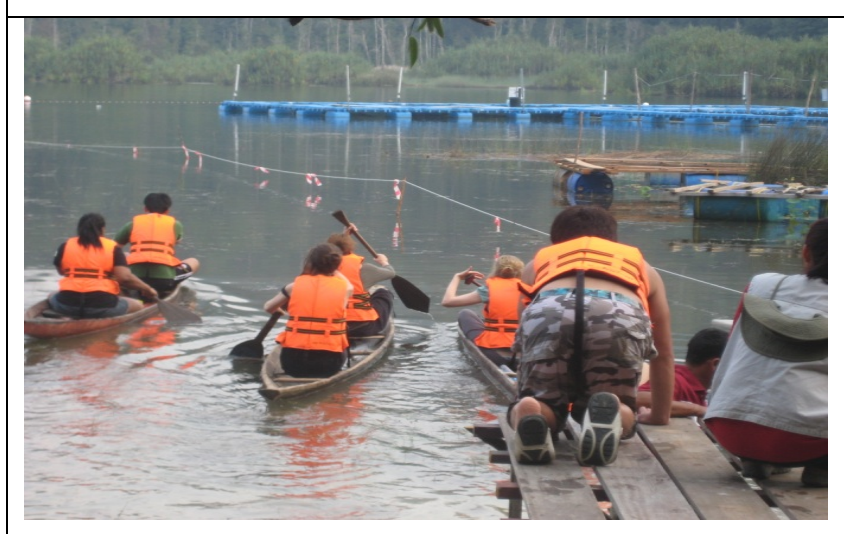

Learning Kayaking

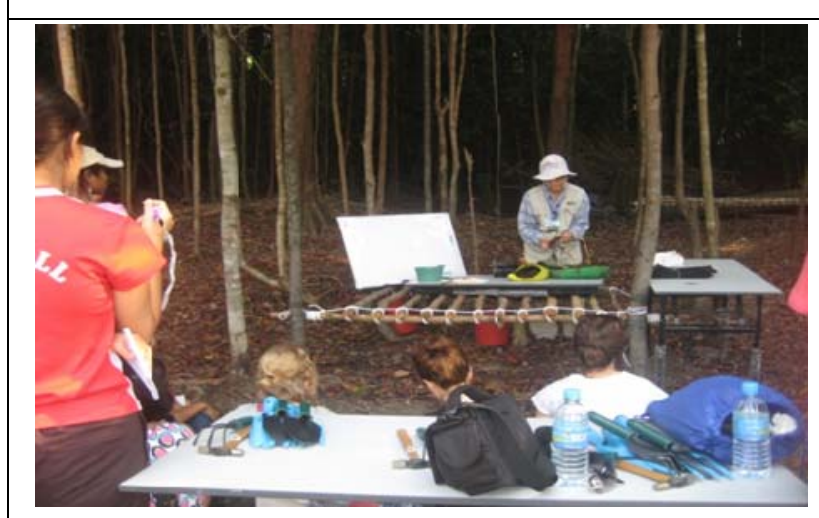

Briefing for Guided Lotus Planting

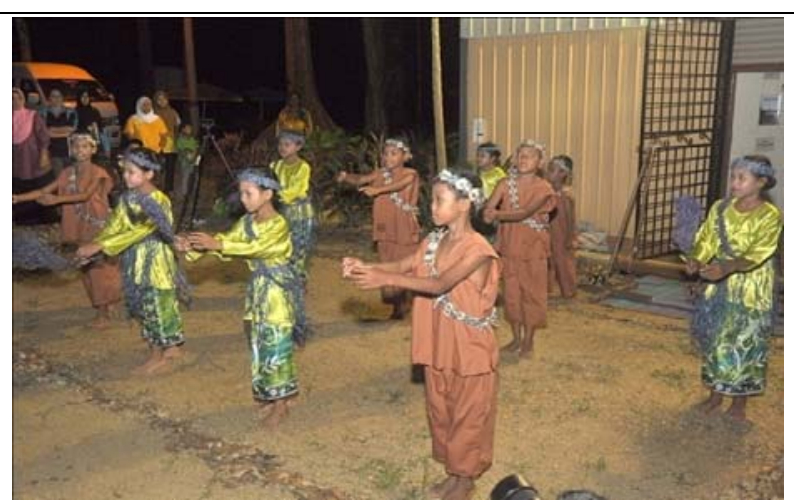

Kelundang Dance

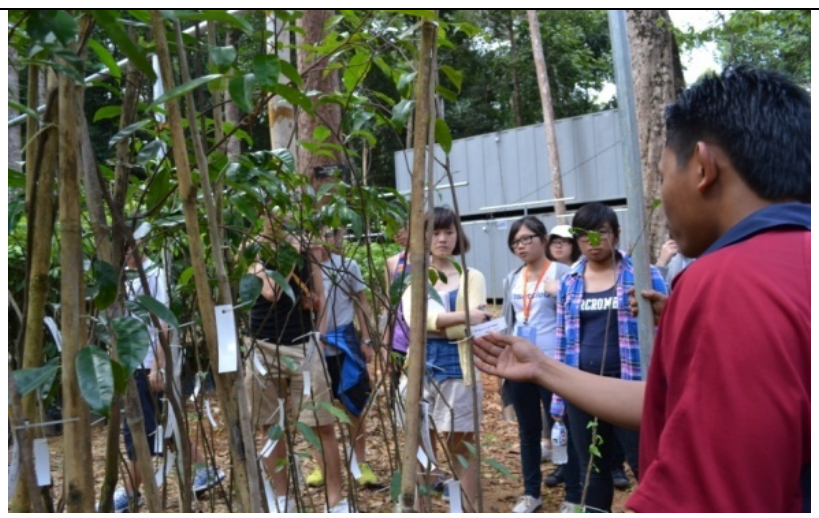

Learning about forest trails with the locals

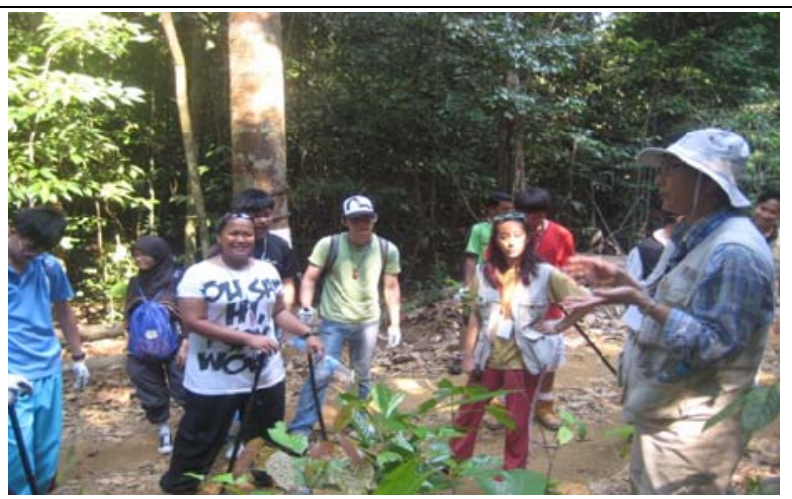

Tree Planting for local food source

Figure 3. The Cultural Learning at Tasik Chini.

an in-depth study of their characteristics and behaviour. Table 4 shows the major segments of the learning community.

Besides recognising the learning community's characteristics, questionnaires were distributed to the participants to provide feedbacks and programme assessment. The results show that appreciation of deep learning in conservation initiatives and eco-hydrological experiments as well as cultural experience of the aboriginals achieved high mean values. Table 5 shows satisfaction of the content, staff and site scored high mean values; on the other hand, accommodation, food and cleanliness only achieved satisfactory mean values.

The results of the international students' survey indicate contradictory perspectives between the local guests the primary school surrounding and within the BR and the matriculation students and participants of the international mobility programmes. Their comments clearly showed that the real community of the BR has yet to be established. Their expectations on various facilities demonstrated that their assessment were made in comparison to the "resort" facilities, while at this juncture, these have 
Table 4. Segments of the Learning Community.

\begin{tabular}{|c|c|}
\hline Potential Market Identified & Market Characteristics \\
\hline Students, undergraduates and graduates & $\begin{array}{l}\text { - Involve both local and international students who seek adventure and knowledge-added value in tour. } \\
\text { - } \quad \text { Work as part-time professional tour guides once completing the tour guide training module. } \\
\text { - } \quad \text { Apply knowledge gained in the classroom into real-life activity. } \\
\text { - } \quad \text { Share knowledge with tourists and local community. }\end{array}$ \\
\hline $\begin{array}{l}\text { Mobility programme, inbound } \\
\text { international students }\end{array}$ & $\begin{array}{l}\text { - Involve both local and international groups. } \\
\text { - } \quad \text { nternational groups act as the ambassadors of their home country by sharing their knowledge and } \\
\text { - } \quad \text { Promote Malaysia as a tourism destination through their report writings. } \\
\text { - Appreciate local culture and heritage through participation with the locals. }\end{array}$ \\
\hline Researchers & $\begin{array}{l}\text { - } \quad \text { Local and international researchers. } \\
\text { - } \quad \text { Contribute to conservation through research, teaching and learning. } \\
\text { - } \quad \text { Assist development of the local economy through guidance, support and knowledge transfer. }\end{array}$ \\
\hline Expatriates and high culture tourists & $\begin{array}{l}\text { - } \quad \text { Involve both local and international high-end k-eco-tourists. } \\
\text { - } \quad \text { Generally educated and demand learning process while vacationing. } \\
\text { - } \quad \text { Willing to spend extra money in exchange for knowledge and experience with the local heritage. } \\
\text { - } \quad \text { Choose professional tour guide services and legitimate tour agencies. }\end{array}$ \\
\hline
\end{tabular}

Table 5. Hospitality Rating of Thematic Programmes of TCBR.

\begin{tabular}{|c|c|c|c|c|c|}
\hline $\begin{array}{l}\text { Please rate for Hospitality } \\
\text { of Thematic Program }\end{array}$ & $\begin{array}{l}\text { Mobility program year } \\
2010 \text { N } 37\end{array}$ & $\begin{array}{l}\text { Mobility program year } \\
2011 \mathrm{~N}-18\end{array}$ & $\begin{array}{l}\text { Mobility program year } \\
2012 \text { N } 16\end{array}$ & $\begin{array}{l}\text { Kembara Pelajar Tasik } \\
\text { Chini N } 76\end{array}$ & $\begin{array}{l}\text { Matriculation students } \\
\text { N-54 }\end{array}$ \\
\hline \multirow[t]{2}{*}{ Year } & 2010 & 2011 & 2012 & 2010 & 2012 \\
\hline & & & Mean & & \\
\hline Services & 4.03 & 3.61 & 3.75 & 4.60 & 4.46 \\
\hline Accommodation & 3.59 & 2.99 & 2.13 & Not rated, day trip only & 4.57 \\
\hline Transportation & 4.32 & 3.61 & 3.56 & 4.50 & 4.58 \\
\hline Food and refreshments & 4.03 & 3.72 & 3.38 & 4.56 & 4.31 \\
\hline Activities & 3.92 & 4.28 & 3.50 & 4.67 & 4.35 \\
\hline Social interaction & 3.95 & 3.89 & 3.94 & 4.51 & 4.51 \\
\hline Facilitators and staffs/experts & 4.32 & 4.22 & 3.94 & 4.60 & 4.31 \\
\hline Cleanliness and safety & 3.41 & 3.17 & 2.81 & 4.51 & 4.31 \\
\hline $\begin{array}{l}\text { Information, content and } \\
\text { approach of the programme }\end{array}$ & 4.16 & 3.67 & 3.51 & 4.67 & 4.80 \\
\hline Site & 4.00 & 4.00 & 3.40 & 4.58 & 4.07 \\
\hline
\end{tabular}

yet to be provided. However, their assessment on the community who hosted the cultural experiences demonstrated that they preferably favour the learning process at the Orang Asli settlement as it offered authentic and real life experience of the Orang Asli's culture. The children on the other hand, were energized with the learning of science in the area of their vicinity and had a better understanding of the Orang Asli livelihood, their closest neighbours within the BR locality. Below are some of the excerpts from their feedback:

Sustainable tourism-friendliness and indigenous interact with people in the city. The Fish Farm-preserves biodiversity, use of algae of research \& monitoring forest.

(N 3 Hong Kong Mobility Student, 2012).

I had an excellent experience of visiting the indigenous people. I learn about their lifestyle and compare to it with Hong Kong lifestyle. What I realised - it seems that we are pursuing too much, much more than we need compared with what the aboriginals had

(N14 Hong Kong Mobility student, 2012).

I learn to be friendlier to nature and environment. Indeed I acquire new knowledge in my own area. Again, I wish to get more exposure on Biosphere reserve

(Children of Kembara Tasik Chini, 2010).

I love learning food web, culture and opportunities in this program make me understand more about Orang Asli - they are my closest neighbour indeed

(Children of Kembara Tasik Chini 2010).

Based on the above mentioned approaches, this study reveals that setting of a learning destination requires a holistic idea of the BR's key roles. Even though Tasik Chini's achievement is still at its infancy stage, several challenges need to be minimized and resolved. These include: 1) The holistic understanding of the sciences of 
the Biosphere Reserve as it combines multi-disciplinary approach and orientation. Pedagogical strategies in learning and teaching Biosphere reserve should be strengthened to ensure variation of knowledge and interests of learners and visitors; 2) The authenticity and creativity of the local players are required to fulfil the knowledge needs of the eco-tourists and visitors. Differences in tourists' origin may increase cultural barriers and practices; 3 ) While the TCBR is a rehabilitation programme, lack of facilities may cause misunderstanding and unsatisfactory experiences; 4) Collaboration between the locals and scientific community remains minimal due to limited funding. While the thrust of the locals towards collaboration is assured, ensuring participations of the locals requires a win-win negotiation and sharing of benefits in the value chain of economy and livelihood. Furthermore, as the locals possess low educational attainment, language barriers and ecotourism ethics are some of the constraints in providing quality services, highlighting the urgency of capacity building and empowerment of human capitals.

\section{Conclusions}

This study provides an understanding of how a Biosphere Reserve functions as a learning destination with three major principles. First, the creation and staging of experience and activities are based on site-specific knowledge of TCBR that are not only concerned with conservation and restoration practices, but in helping to build and inculcate awareness of sustainable development of the lake and wetland ecosystem. The second is the integration of players from the local communities that is equally significant in providing real life experience, tradition and involvement of the community. Third, the existence of the learning community must be ensured as this drives the sustainability of the inbound market of LTD.

The site specific knowledge, however, should not only cover scientific orientation as most of the eco-tourists or Biosphere learners also seek opportunities to experience the cultural flavour of the locals. Staging of the local cultural tradition in the villages is more appreciated as their surroundings are real and authentic. Additionally, taking ecotourism into conservation and rehabilitation programme is also appreciated but should not be overemphasized because of the short duration of visits and leisure time to freely experience the natural surroundings. Longer duration will be recommended only when these learners need to engage in scientific experiments.

Overall, even though this initiative is still at its very infancy, undertakings the knowledge eco-tourists experiences could be the platform to segment the learners to ensure better function of the Learning Destination. It is recommended that the principles of the scientific and local knowledge become the thrust of LTD of Tasik Chini.

\section{Acknowledgements}

The authors are grateful to all stakeholders in Tasik Chini who kindly devoted their precious time for the interview process and data collection. The work was funded by the Top Down-FRGS Grant, entitled Lake Ecosystem Assessment of Tasik Chini, and Long Term Research Grant: Managing the Science of Biosphere Reserve, from the Ministry of Education, Malaysia as well as the Faculty of Social Sciences and Humanities Research Development Grant DPP-2013-169, 2013.

\section{REFERENCES}

[1] UNESCO, "The Man and the Biosphere (MAB) Programme," 2012.

http://www.unesco.org/new/en/natural-sciences/environm ent/ecologicalsciences/man-and- biosphere-programme/

[2] UNESCO, "UNESCO Biosphere Reserves: Learning Laboratories for Sustainable Development," 2007. http://unesdoc.unesco.org/images/0015/001516/151607e.pdf

[3] N. Ishwaran, "Science in Intergovernmental Environmental Relations: 40 Years of UNESCO's Man and the Biosphere (MAB) Programme and Its Future," Environmental Development, Vol. 1, No. 1, 2012, pp. 91-101. http://dx.doi.org/10.1016/j.envdev.2011.11.001

[4] N. Ishwaran, A. Persic and N. H. Tri, "Concept and Practice: The Case of UNESCO Biosphere Reserves," International Journal of Environment and Sustainable Development, Vol. 7, No. 2, 2008, pp. 118-131.

http://dx.doi.org/10.1504/IJESD.2008.018358

[5] D. Kušová, J. Těšitel, $K$. Matějka and M. Bartoš, "Biosphere Reserves-An Attempt to Form Sustainable Landscapes: A Case Study of Three Biosphere Reserves in the Czech Republic," Landscape and Urban Planning, Vol. 84, No 1, 2008, pp. 38-51.

[6] J. Kriesel, "Education for Sustainable Development in the Biosphere Reserves Schaalsee, Germany, and Kristianstads Vattenrike, Sweden," Diploma Thesis, University of Greifswald, 2011.

http://www.mnf.unigreifswald.de/fileadmin/Geowissensc haften/geographie/angew_geo/Diplomarbeiten/Janin_Krie sel_Diplomar beit_BNE.pdf

[7] Y. Luo and J. Deng, "The New Environmental Paradigm and Nature-Based Tourism Motivation," Journal of Travel Research, Vol. 46, No. 4, 2008, pp. 392-402. http://dx.doi.org/10.1177/0047287507308331

[8] M. Batisse, "Biosphere Reserves, a Challenge for Biodiversity Conservation and Regional Development," Environment, Vol. 39, No. 5, 1997, pp. 7-33. http://dx.doi.org/10.1080/00139159709603644

[9] J. J. Kay, H. Regier, M. Boyle and G. R. Francis, "An Ecosystem Approach for Sustainability: Addressing the Challenge of Complexity," Futures, Vol. 31, No. 7, 1999, pp. 721-742.

http://dx.doi.org/10.1016/S0016-3287(99)00029-4

[10] C. Canning, "Conservation and Local Communities: Exploring the Upper Bay of Fundy Biosphere Reserve Ini- 
tiative in Nova Scotia," 2005.

http://www.bofep.org/PDFfiles/Caroline_Canning_Final_ 20Thesis.pdf

[11] L. Kruse-Graumann, "Education for Sustainable Development in German Biosphere Reserves," 2007. http://www.unesco.de/fileadmin/medien/Dokumente/unes co-heute/uh2-07-p22-26.pdf

[12] J. N. Pretty, I. Guijt, J. Thompson and I. Scoones, "Participatory Learning and Action: A Trainer's Guide," IIED, London, 1995.

[13] M. F. Price, "The Periodic Review of Biosphere Reserves: A Mechanism to Foster Sites of Excellence for Conservation and Sustainable Development," Environmental Science \& Policy, Vol. 5, No. 1, 2002, pp. 13-18. http://dx.doi.org/10.1016/S1462-9011(02)00021-7

[14] D. McCarthy, G. Whitelaw, P. Jongerden and B. Craig, "Sustainability, Social Learning and the Long Point World Biosphere Reserve," Environments Journal, Vol. 34, No. 2, 2006, pp. $1-15$.

[15] J. Tippett, B. Searle, C. Pahl-Wostl and Y. Rees, "Social Learning in Public Participation in River Basin Management-Early Findings from Harmony COP European Case Studies," Environmental Science and Policy, Vol. 8, No. 3, 2005, pp. 287-299. http://dx.doi.org/10.1016/j.envsci.2005.03.003

[16] T. Van Mai and O. J. H. Bosch, "Systems Thinking Approach as a Unique Tool for Sustainable Tourism Development: A Case Study in the Cat Ba Biosphere Reserve of Vietnam," 2010. www.systemdynamics.org/conferences/2010/proceed/.../P 1312.pdf

[17] N. C. Nguyen, O. J. H Bosch and K. E. Maani, "The Importance of Systems Thinking and Practice for Creating Biosphere Reserves as Learning Laboratories for Sustainable Development," 2009.

http://journals.isss.org/index.php/proceedings53rd/article/ view/1161/398

[18] K. Schianetz, L. Kavanagh and D. Lockington, "The Learning Tourism Destination: The Potential of a Learning Organisation Approach for Improving the Sustainability of Tourism Destinations," Tourism Management, Vol. 28, No. 6, 2007, pp. 1485-1496. http://dx.doi.org/10.1016/j.tourman.2007.01.012

[19] K Schianetz, J. Tod, L. Kavanagh, P. A. Walker, D. Lockington and D. Wood, "The Practicalities of a Learning Tourism Destination: A Case Study of the Ningaloo Coast," International Journal of Tourism Research, Vol. 11 , No. 6, 2009, pp. 567-581. http://dx.doi.org/10.1002/jtr.729

[20] H. Gibson, "The Educational Tourist," Journal of Phvsical Education, Recreation and Dance, Vol. 69, No. 4, 1998, pp. 32-34. http://dx.doi.org/10.1080/07303084.1998.10605533

[21] A. Holdnak and S. Holland, "Edutourism: Vacationing to Learn," Parks and Recreation, Vol. 31, No. 9, 1996, pp. 72-75.

[22] Ministry of British Colombia, "The Environmental Learning and Experience. Curriculum Map Environment and Sustainability across Bc's K-12 Curric," 2009. http://www.bced.gov.bc.ca/environment_ed/ele_maps.pdf

[23] S. De la Barre, "Learning Travel Product Development Workbook: A Step-By-Step Guide for Yukon and Northern Entrepreneurs, North to Knowledge (N2K), Whitehorse, Yukon," 2005.

http://www.tc.gov.yk.ca/pdf/LearningTravelProductDevel opmentWorkbook.pdf

[24] M. Flitner, U. Matthes, G. Oesten and A. Roeder, "The Ecosystem Approach in Forest Biosphere Reserves: Results from Three Case Studies," Albert-Ludwigs-Universität Freiburg, Freiburg, 2006. http://www.bfn.de/fileadmin/MDB/documents/skript168.pdf

[25] H. L. Ballard, M. E. Fernandez-Gimenez and V. E. Sturtevant, "Integration of Local Ecological Knowledge and Conventional Science: A Study of Seven CommunityBased Forestry Organizations in The USA," Ecology and Society, Vol. 13, No. 2, 2008, p. 37.

http://www.ecologyandsociety.org/vol13/iss2/art37/

[26] G. E. Yates, T. V. Stein and M. S. Wyman, "Factors for Collaboration in Florida's Tourism Resources: Shifting Gears from Participatory Planning to Community-Based Management," Landscape and Urban Planning, Vol. 97, 2010, pp. 213-220.

[27] C. Lashley and P. Barron, "The Learning Style Preferences of Hospitality and Tourism Students: Observations from an International and Cross-Cultural Study," International Journal of Hospitality Management, Vol. 25, No. 4, 2006, pp. 552-569.

http://dx.doi.org/10.1016/j.ijhm.2005.03.006

[28] J. Purkayastha, S. C. Nath and M. Islam, "Ethnobotany of Medicinal Plants from Dibru-Saikhowa Biosphere Reserve of Northeast India," Fitoterapia, Vol. 76, No. 1, 2005, pp. 121-127.

http://dx.doi.org/10.1016/j.fitote.2004.10.012

[29] K. S. Rao, R. K. Maikhuri, S. Nautiyal and K. G. Saxena, "Crop Damage and Livestock Depredation by Wildlife: A Case Study from Nanda Devi Biosphere Reserve, India," Journal of Environmental Management, Vol. 66, No. 1, 2002, pp. 317-327.

[30] S. K., Singh, J. P. N. Rai and A. Singh, "Influence of Prevailing Disturbances on Soil Biology And Biochemistry of Montane Habitats at Nanda Devi Biosphere Reserve (NDBR), India During Wet and Dry Seasons," Geoderma, Vol. 162, No. 3-4, 2011, pp. 296-302. http://dx.doi.org/10.1016/j.geoderma.2011.02.014

[31] D. Manuel-Navarrete, S. Slocombe and B. Mitchell, "Science for Place-Based Socioecological Management: Lessons from the Maya Forest (Chiapas and Petén)," Ecology and Society, Vol. 11, No. 1, 2006, p. 8. http://www.ecologyandsociety.org/ vol 11/ iss1/ art8/

[32] G. Francis and G. Whitelaw, "Biosphere Reserves in Canada: Exploring Ideals and Experience," Environment, Vol. 32, No. 3, 2004, pp. 61-78.

[33] V. Christidou, "Interest, Attitudes and Images Related to Science: Combining Students' Voices with the Voices of School Science, Teachers, and Popular Science," International Journal of Environmental \& Science Education, Vol. 6, No. 2, 2011, pp. 141-159.

[34] A. Watson, L. Alessa and B. Glaspell, "The Relationship 
between Traditional Ecological Knowledge, Evolving Cultures, and Wilderness Protection in the Circumpolar North," Conservation Ecology, Vol. 8, No. 1, 2003, p. 2. http://www. consecol.org/ vol8/iss1/ art2

[35] G. Boucher, C. Conway and E. V. Der Meer, "Tiers of Engagement by Universities in their Region's Development," Regional Studies, Vol. 37, No. 9, 2003, pp. 887889. http://dx.doi.org/10.1080/0034340032000143896

[36] D. Buss, "Secret Destinations. Creativity or Conformity? Building Cultures of Creativity in Higher Education," A Conference Organised by the University of Wales Institute, Cardiff in Collaboration with the Higher Education Academy, Cardiff, 8-10 January 2007.

http:www.creativityconference07.org/presented_papers/B uss_Secret.doc

[37] O. Zbyranyk, "Collaboration between Researchers and Biosphere Reserve Practitioners: A Case Study of Redberry Lake Biosphere Reserve, Canada," Thesis, University of Saskatchewan Saskatoon, 2012. http://ecommons.usask.ca/bitstream/handle/10388/ETD-2 012-09-654/ZBYRANYK-THESIS.pdf? sequence=4

[38] L. Schultz and C. Lundholm, "Learning for Resilience? Exploring Learning Opportunities in Biosphere Reserves," Environmental Education Research, Vol. 16, No. 5, 2010, pp. 645-663. http://dx.doi.org/10.1080/13504622.2010.505442

[39] P. K. Ankomah and R. T. Larson, "Education Tourism: A Strategy to Strategy to Sustainable Tourism Development in Sub-Saharan Africa," 2000. http://www.unpan1.un.org/intradoc/groups/public/docum ents/.../UNPAN002585

[40] J. Coria and E. Calfucura, "Ecotourism and the Development of Indigenous Communities: The Good, the Bad, and the Ugly," Ecological Economics, Vol. 73, 2012, pp. 47-55.

[41] M. Galliford, “Touring 'Country', Sharing 'Home': Aboriginal Tourism, Australian Tourists and The Possibilities for Cultural Transversality," Tourist Studies, Vol. 10, No. 3, 2010, pp. 227-244. http://dx.doi.org/10.1177/1468797611407759

[42] A. Habibah, J. Hamzah, I. Mushrifah, A. Buang, M. E. Toriman and K. Jusoff, "The Success Factors of Public Consultation in the Establishment of a Biosphere Reserve -Evidence from Tasik Chini," World Applied Science Journal, Vol. 13, 2011, pp. 74-81.

[43] A. Habibah, I. Mushrifah, J. Hamzah, M. E. Toriman, A. Buang, K. Jusoff, M. J. Mohd Fuad, A. C. Er and A. M. Azima, "Assessing Natural Capital for Sustainable Ecotourism in Tasik Chini Biosphere Reserve," Advances in Natural and Applied Sciences, Vol. 6, No. 1, 2012, pp. $1-9$.

[44] A. Habibah, R. Mohamed, I. Mushrifah, J. Hamzah, M. N. Aimi Syairah and A. Buang, "Positioning University as Knowledge Ecotourism Destination: Key Success Factors," International Business Management, Vol. 6, No. 1, 2012, pp. 32-40.

http://dx.doi.org/10.3923/ibm.2012.32.40 